\title{
Wood growth of Tabebuia barbata (E. Mey.) Sandwith (Bignoniaceae) and Vatairea guianensis Aubl. (Fabaceae) in Central Amazonian black-water (igapó) and white-water (várzea) floodplain forests
}

\author{
Sinomar Ferreira da Fonseca Júnior • \\ Maria Teresa Fernandez Piedade · Jochen Schöngart
}

Received: 13 February 2008/Revised: 19 July 2008/ Accepted: 1 August 2008 / Published online: 22 August 2008

(C) The Author(s) 2008. This article is published with open access at Springerlink.com

\begin{abstract}
Tree growth is a fundamental indicator for conservation plans of Amazonian floodplain forests. In this study we use dendrochronology to analyze wood growth patterns of Tabebuia barbata and Vatairea guianensis, two tree species occurring in nutrient-rich white-water (várzea, Mamirauá Sustainable Development Reserve, MSDR) and nutrient-poor black-water (igapó, Amanã Sustainable Development Reserve, ASDR) floodplain forests of Central Amazonia. From 20 trees per species and floodplain system (total of 80 trees) growing under a similar flooding regime with a mean inundation height of about $4 \mathrm{~m}$ we measured diameter at breast height (dbh). We sampled two cores per tree with an increment corer at the height of dbh to determine wood density (WD), tree age and mean radial increment (MRI) rates. The wood samples were macroscopically analyzed. Both tree species show distinct annual tree rings characterized by marginal parenchyma tissues. MRI was measured by a digital measuring device and WD was determined by the ratio dry mass/fresh volume. MRI of both tree species was significantly higher in the várzea than in the igapó, which can be traced back to the contrasting nutrient status. WD showed no difference comparing both
\end{abstract}

Communicated by R. Aloni.

S. F. da Fonseca Júnior · M. T. F. Piedade · J. Schöngart ( $\square)$ Instituto Nacional de Pesquisas da Amazônia/Max-Planck Project, Av. André Araújo 2936, P.O. Box 478, 69011-970 Manaus, Amazonas, Brazil

e-mail: jschoen@gwdg.de

J. Schöngart

Biogeochemistry Department, Max-Planck-Institute

for Chemistry, Joh.-J.-Becherweg 27,

Universitätscampus, 55128 Mainz, Germany floodplain forest types. Tree ages of a species for the same diameter are more than twofold higher in the igapó than in the várzea. To insure a sustainable harvest, felling cycles in these forests should be adjusted according to rates of growth.

Keywords Amazon - Floodplain forest .

Dendrochronology $\cdot$ Forest management $\cdot$ Conservation

\section{Introduction}

The Central Amazonian floodplain forests along the large river systems are an aquatic-terrestrial transition zone (Junk et al. 1989), because they alternate annually between a flooded and a non-flooded phase triggered by a monomodal flood-pulse with a mean amplitude of about $10 \mathrm{~m}$ (Schöngart and Junk 2007). Forests cover about 50-75\% of the floodplain system and are the main vegetation type (Wittmann et al. 2002). Floodplain forests are of extreme importance for the fluvial ecosystems functioning as sinks and sources in the biogeochemical cycles, regulating the hydrological systems, acting as habitats for a high biodiversity of partial endemic plant and animal species and delivering natural resources for the human populations (Wittmann et al. 2006). The floodplain forests can be distinguished by their nutrient status into the igapó and the várzea (Prance 1979). The igapó covers about $100,000 \mathrm{~km}^{2}$ and is influenced by clear-water or blackwater rivers draining the geochemically poor watersheds of the Central Brazilian shield and the Guyanas. The water has low $\mathrm{pH}$ and nutrient status. The várzea $\left(\sim 200,000 \mathrm{~km}^{2}\right)$ is fed by the white-water rivers originating from the Andean catchments bringing high amounts of nutrient-rich sediments into the Central Amazonian 
floodplains which is deposited during the flooded period. Therefore the soils of the várzea floodplains contain much higher stocks of macro and micronutrients than the igapó (Furch 1997).

The existence of the monomodal flood-pulse for millions of years (Junk 1989) enabled the adaptation for hundreds of tree species to these extreme flooding conditions resulting in different forest types along hydrological, edaphic and successional gradients (Wittmann et al. 2006). The annual long-term flooding results in phenological, morphological and physiological responses of the trees (Parolin et al. 2004) and triggers the growth rhythm of many floodplain species (Schöngart et al. 2002). Flooding causes anaerobic conditions in the soils (Worbes 1997) leading to a reduction of root activity and root respiration at the beginning of the aquatic phase. During this period, the trees replace their leaves and start flowering and fruiting (Schöngart et al. 2002). Wood growth is mainly restricted to the terrestrial phase (vegetation period). During 3-4 months of the aquatic phase the cambium is dormant leading to the formation of an annual tree ring (Worbes 1988; Schöngart et al. 2002). The analysis of treering sequences (dendrochronology) is a powerful tool for a rapid and accurate assessment of tree growth during the past comprising decades and centuries. This method is of extreme importance to obtain information on tree ages and diameter increment rates (Dünisch et al. 2003). In the Central Amazonian floodplain forests dendrochronology has been successfully applied to model climate-growth relationships (Schöngart et al. 2004, 2005), carbon sequestration (Schöngart 2003) and the definition of species-specific management criteria (Schöngart et al. 2007; Schöngart 2008).

In Central and Western Amazonia 60-90\% of the timber originates from floodplain forests (Kvist and Nebel 2001; Worbes et al. 2001; Lima et al. 2005), due to the easy access and the low costs for harvesting, skidding and transport of the logs (Higuchi et al. 1994; Barros and Uhl 1995). However, such timber extraction concentrates on a few tree species such as Cedrela odorata, Calophyllum brasiliense, Ceiba pentandra, Virola surinamensis and Platymicium ulei. Timber harvesting in the floodplains is unsustainable because of the gaps of knowledge on growth rates and regeneration patterns of these species (Schöngart et al. 2007; Schöngart 2008). Diameter increment rates are a robust indicator for the dynamical processes of a forest ecosystem (Brienen and Zuidema 2006). Such data are important for the development of conservation plans by sustainable management or preservation. In this study we apply dendrochronology to determine tree age and mean diameter increment rates of the tree species Vatairea guianensis and Tabebuia barbata, which occur in both floodplain forest types.

\section{Materials and methods}

Study area

The study was performed in the Central Amazonian Conservation Complex of about $6 \times 10^{6}$ ha (Ayres et al. 2005), declared a world natural heritage site by UNESCO in 2000 with an extension in 2003 comprising the Jaú National Park and the two Reserves for Sustainable Development, Mamirauá (MSDR) and Amanã (ASDR) (Fig. 1). The MSDR $\left(11,240 \mathrm{~km}^{2}\right)$ comprises only várzea ecosystems surrounded by the Solimões and Japurá rivers, while the ASDR $\left(23,500 \mathrm{~km}^{2}\right)$ is a patchwork of várzea, igapó and mainly non-flooded forests (terra firme). For this study we compared tree growth of populations of $T$. barbata and $V$. guianensis between the várzea site "Mujuí" in the MSDR $\left(02^{\circ} 50^{\prime} \mathrm{S}, 64^{\circ} 54^{\prime} \mathrm{W}\right)$ and the igapó site "Bacaba" along the left shore of the Amanã lake $\left(02^{\circ} 33^{\prime} \mathrm{S}\right.$, $\left.64^{\circ} 41^{\prime} \mathrm{W}\right)$ in the ASDR. The distance between the two sites is approximately $40 \mathrm{~km}$. A mean annual temperature of $26.9^{\circ} \mathrm{C}$ and an average annual precipitation of about $3,000 \mathrm{~mm}$ characterize the climate in the study region with a distinct dry season from July to October (Sombroek 2001; Schöngart et al. 2005). Both reserves have been created by the governor of the Amazonas state with the objective to develop sustainable management plans for the natural resources through active participation of the local human populations based on socio-economic and ecological-biological studies (Ayres et al. 1998). Since 2000, forest management plans have been executed in the MSDR based on Brazilian forest laws and Normative Instructions (IN) by the Brazilian Institute of Environment and Renewable Natural Resources (IBAMA). The IN number 5 from 11th December 2006 establishes forest management plans for polycyclic systems (selective logging) with felling cycles between 25 and 35 years, a minimum logging diameter (MLD) of $50 \mathrm{~cm}$ and a maximum yield of $30 \mathrm{~m}^{3} \mathrm{ha}^{-1}$. For várzea forests, a felling cycles of 10 years can be applied restricted to a maximum yield of $10 \mathrm{~m}^{3} \mathrm{ha}^{-1}$. More than 40 timber species are extracted in the MSDR, but the sustainability of this forest management must be questioned due to the missing information on tree growth, regeneration and establishment (Schöngart 2008).

\section{Tree species}

We selected the tree species T. barbata (Bignoniaceae) and $V$. guianensis (Fabaceae) for our study, because they are of commercial importance and occur in both floodplain forest types achieving high abundances (Ferreira 1997; Schöngart 2003; Parolin et al. 2004; Wittmann et al. 2006). Both species are deciduous, shedding their leaves at the beginning of the aquatic phase (February/March) and remaining 
Fig. 1 Study sites located in the Mamirauá and Amanã Sustainable Development Reserves (MSDR, ASDR) in Central Amazonian Conservation Complex, Brazil

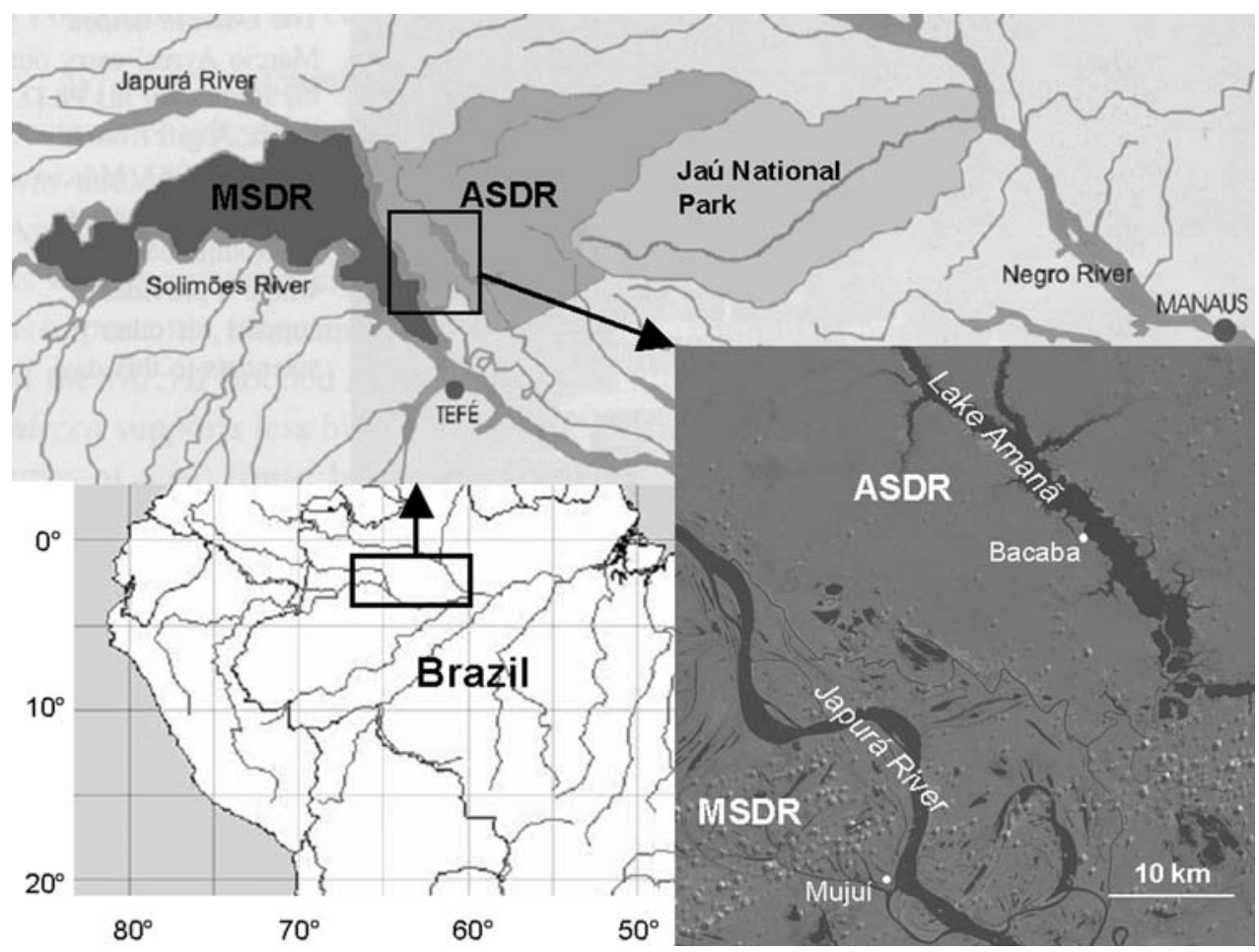

bare for several weeks (Schöngart et al. 2002). Flowering occurs during December to May (T. barbata) and February/ March (V. guianensis), while fruiting is restricted to the flooded period during March to June (T. barbata) and April to June (V. guianensis) (Schöngart et al. 2002; J. Schöngart, personal observation). T. barbata, known as capitarí in Central Amazonia, occurs in late successional stages, but occasionally appears also in earlier successional stages (Worbes 1988) of the low várzea inundated between 3 and $6 \mathrm{~m}$ on average per year (Wittmann et al. 2002). In the igapó the species establishes in old-growth forests under similar hydrological conditions. Local people use the wood as posts and lumber for construction (Wittmann et al. 2008). V. guianensis, known as faveira in the Central Amazon region, is a non-pioneer species dominating late successional stages in the low várzea and old-growth forests in the igapó (Parolin and Ferreira 1998; Schöngart 2003). The wood is used and commercialized mainly for house construction (Loureiro et al. 2000).

\section{Fieldwork}

Fieldwork was realized during two excursions in February 2006 and August 2006. At each site 20 trees of a species with diameter at breast height $(\mathrm{dbh})>20 \mathrm{~cm}$ were selected in old-growth forests at similar elevations of the várzea and igapó yielding a total number of 80 trees. From every tree $\mathrm{dbh}$, measured $1.30 \mathrm{~m}$ above the ground, and the floodheight of every tree, visible as a distinct mark of the last high-water period on the trunk, were recorded. Two wood samples per tree were taken from $1.30 \mathrm{~m}$ with an increment corer ( $5 \mathrm{~mm}$ in diameter) to determine tree age and mean radial increment (MRI) as well as wood density (WD).

Sample preparation, ring-width measurements and data treatment

The wood samples were analyzed in the Dendrochronological Laboratory of the National Institute for Amazon Research (INPA) in Manaus. From one core we calculated WD after $72 \mathrm{~h}$ drying at a temperature of $105^{\circ} \mathrm{C}$ by the ratio dry weight/fresh volume (Schöngart et al. 2005). With the second sample we determined tree age and MRI rates by dendrochronological methods. The cores were clued on wooden supports and polished with sand paper of decreasing grain size from 40 to 600 grits and cleaned with compressed air. Tree rings were dated by their wood anatomical structure characterized by marginal parenchyma bands (Worbes 1988) using a microscope (Leica MZ 8) (Fig. 2). Ring-width was measured with a digital measuring device (LINTAB) to the nearest $0.01 \mathrm{~mm}$ supported with software for tree-ring measurement, analysis and presentation (TSAP-Win, Rinntech, Heidelberg, Germany). The tree age was determined by counting of tree rings. For cores that did not include the pith of the tree, the age was estimated by the measured dbh and the determined MRI on the wood sample (Schöngart et al. 2005). At each site we calculated correlations between the parameters tree age, 
Fig. 2 Wood anatomical structure of $V$. guianensis and T. barbata from the igapó and várzea. Ring boundaries are characterized by marginal parenchyma bands and indicated by arrows
Tabebuia barbata

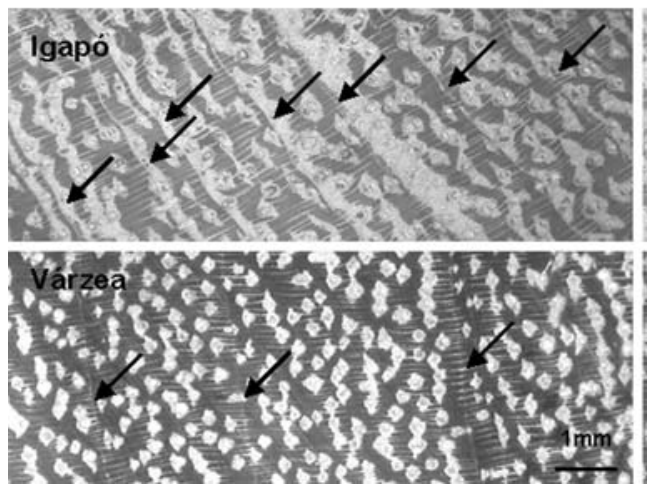

Vatairea guianensis
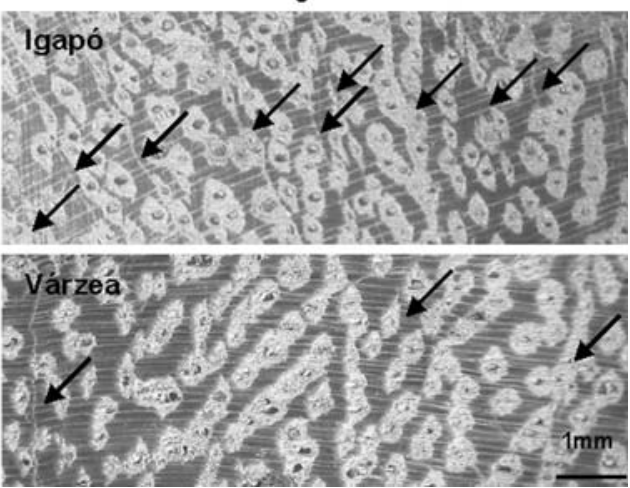

dbh, WD and MRI of a species. T-tests were performed to highlight significant differences between tree age, MRI and WD of a tree species at different sites (Statistica 6.0, Schöngart et al. 2005). Based on the relationship between dbh and MRI, cumulative diameter growth was modeled accumulating the MRI rates with increasing tree age. To estimate the felling cycle the mean time through $10-\mathrm{cm}$ diameter classes until achieving the MLD of $50 \mathrm{~cm}$ was calculated (Schöngart et al. 2007; Schöngart 2008). This period represented the average time, which an individual needs to grow from one to the next diameter class.

\section{Results}

The two populations of T. barbata and V. guianensis in the igapó and the várzea grow under almost the same flooding regime, inundated by a mean water column up to 380$420 \mathrm{~cm}$, corresponding to a mean inundation period of 160-173 days (Table 1). Both species had distinct tree rings allowing reliable analysis. The mean dbh of the studied trees of $T$. barbata is smaller in the igapó $(\mathrm{dbh}=29.4)$ than in the várzea $(\mathrm{dbh}=44.1)$. Tree age of
T. barbata is not significantly different between the populations in the igapó (92 \pm 33 years) and the várzea (84 \pm 28 years), but MRI is significantly lower in the igapó $\quad(\mathrm{MRI}=1.71 \pm 0.50)$ than in the várzea $(\mathrm{MRI}=2.88 \pm 1.00)$ (Fig. 3). No differences are indicated between WD comparing igapó $(\mathrm{WD}=0.83 \pm$ $0.08 \mathrm{~g} \mathrm{~cm}^{-3}$ ) and várzea $\left(\mathrm{WD}=0.80 \pm 0.08 \mathrm{~g} \mathrm{~cm}^{-3}\right)$. $V$. guianensis had a higher mean dbh $(56.9 \mathrm{~cm})$ and lower tree ages $(91 \pm 37$ years) in the várzea than in the igapó $(102 \pm 45$ years for a mean dbh of $43.2 \mathrm{~cm})$, resulting in significant differences between MRI in the igapó $(\mathrm{MRI}=2.29 \pm 0.70)$ compared to the várzea $(\mathrm{MRI}=$ $3.59 \pm 1.53$ ) (Fig. 3). This species had a lower WD than T. barbata, but again, there was no difference in WD between the igapó (WD $=0.65 \pm 0.04 \mathrm{~g} \mathrm{~cm}^{-3}$ ) and várzea $\left(\mathrm{WD}=0.66 \pm 0.03 \mathrm{~g} \mathrm{~cm}^{-3}\right)$.

In all cases tree age correlated negatively with MRI (Table 2). In the igapó both tree species indicate significant correlations between $\mathrm{dbh}$ and tree age. Furthermore, $T$. barbata indicates a negative correlation between MRI and WD at the igapó site. Based on the significant negative relationships between tree age and MRI we developed cumulative growth curves by non-linear regression

Table 1 Mean flood-height, sample size, diameter at breast height (dbh), tree age, mean radial increment (MRI) and wood density (WD) of $V$. guianensis and T. barbata from Central Amazonian floodplain forests of várzea (nutrient-rich) and igapó (nutrient-poor)

\begin{tabular}{|c|c|c|c|c|c|c|}
\hline & \multicolumn{3}{|l|}{ Tabebuia barbata } & \multicolumn{3}{|c|}{ Vatairea guianensis } \\
\hline & Igapó & Várzea & $T$-value & Igapó & Várzea & $T$-value \\
\hline Sample size & $n=20$ & $n=20$ & & $n=20$ & $n=20$ & \\
\hline Mean flood-height (m) & 4.0 & 4.2 & & 3.8 & 4.2 & \\
\hline Inundation period (days) & 167 & 173 & & 160 & 172 & \\
\hline Mean dbh $(\mathrm{cm})(\min -\max )$ & $29.4(21.3-42.9)$ & $44.1(34.0-60.0)$ & & $43.2(25.0-64.5)$ & $56.9(42.5-84.1)$ & \\
\hline $\mathrm{MRI}(\mathrm{mm})($ mean $\pm \mathrm{SD})$ & $1.71 \pm 0.51$ & $2.88 \pm 1.00$ & $4.64 *$ & $2.29 \pm 0.70$ & $3.59 \pm 1.53$ & $3.45^{*}$ \\
\hline Tree age (years) $($ mean \pm SD) & $92 \pm 33$ & $84 \pm 28$ & 0.77 (ns) & $102 \pm 45$ & $91 \pm 37$ & $0.92(\mathrm{~ns})$ \\
\hline $\mathrm{WD}\left(\mathrm{g} \mathrm{cm}^{-3}\right)($ mean $\pm \mathrm{SD})$ & $0.83 \pm 0.08$ & $0.80 \pm 0.08$ & $1.02(\mathrm{~ns})$ & $0.65 \pm 0.04$ & $0.66 \pm 0.03$ & $0.84(\mathrm{~ns})$ \\
\hline
\end{tabular}

Mean radial increment differs significantly between trees from both systems as indicated by $T$-test ( $P$ : confidence-level)

$n s$ Not significant

$* P<0.001$ 


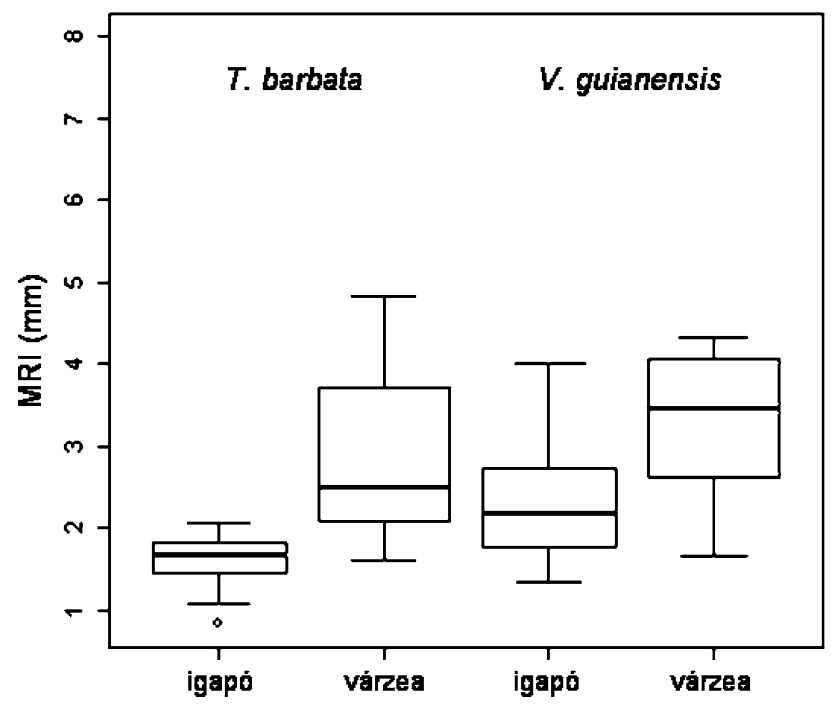

Fig. 3 Differences in mean radial increment of $T$. barbata and $V$. guianensis in the igapó and várzea

analyses for both species in the contrasting floodplain types (Fig. 4). On average, in the várzea, T. barbata achieves the MLD of $50 \mathrm{~cm}$ in 117 years, whereas in the igapó the species needs more than 270 years to pass over this limit (Fig. 5). V. guianensis indicates faster tree growth than $T$. barbata and passes over the MLD within 70 years in the várzea, and 162 years in the igapó. Estimations of felling cycles yield 23.4 years for $T$. barbata in the várzea, and 55.6 years in the igapó (Fig. 6), while for $V$. guianensis felling cycles are 14.0 years in the várzea and 32.4 years in the igapó.

\section{Discussion}

The existence of annual tree rings of many tree species in Amazonian floodplain forests has been indicated by several independent dendrochronological methods such as wood anatomical descriptions, cambial wounding, measurements of the cambial resistance by a shigometer, phenological

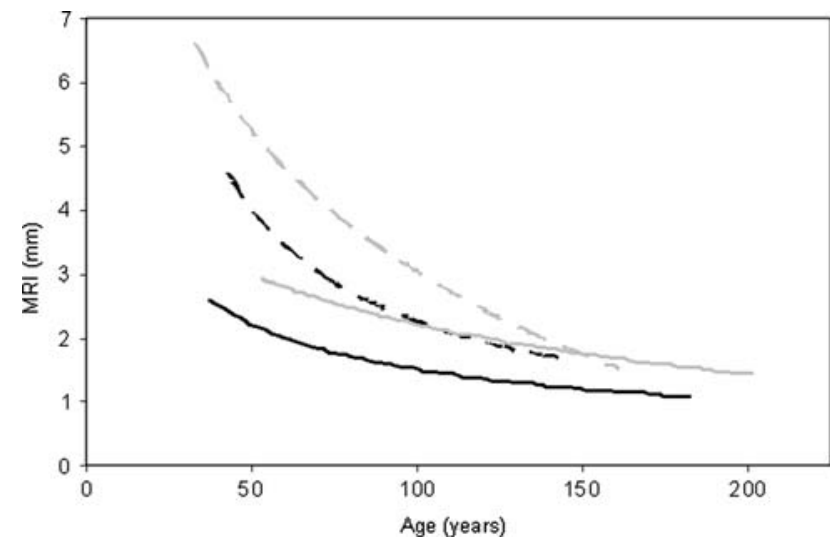

Fig. 4 Non-linear relationship between tree age and mean radial increment of $T$. barbata (black) and V. guianensis (gray) in the igapó (continuous line) and várzea (dotted line). T. barbata, igapó: MRI $=19.25 \times$ tree age ${ }^{-0.5520}, T$. barbata, várzea: MRI $=-2.47$ Ln(tree age $)+13.69, V$. guianensis, igapó: $\mathrm{MRI}=20.14 \times$ tree age $^{-0.4872}$, V. guianensis, várzea: $\mathrm{MRI}=-3.20 \mathrm{Ln}($ tree age $)+$ 17.78

observations, dendrometers, densitometry, radiocarbon dating and climate-growth relationships (Worbes 1988, 1989, 1997; Worbes et al. 1995; Schöngart et al. 2002, 2004, 2005). In this study we apply dendrochronology to show how wood growth of a tree species varies in forest types of Amazonian floodplains with different nutrient status. Since both tree populations grow under a similar flooding regime, these differences can be traced back to the differing nutrient supply between várzea and igapó (Furch 1997), also shown for the study area at Lake Amanã (Rodrigues 2007). In the alluvial soils of the várzea, nutrient concentrations of macroelements such as $\mathrm{P}, \mathrm{K}, \mathrm{Ca}$ and $\mathrm{Mg}$ as well as micronutrients such as $\mathrm{Fe}, \mathrm{Zn}, \mathrm{Mn}$ are 5-15 times higher than in the igapó. This difference is also reflected in the living aboveground biomass of trees comparing the two floodplain types where the nutrient stocks are up to four times higher in the várzea than in the igapó.

Parolin and Ferreira (1998) found for some tree species a lower WD in the igapó than in the várzea and suggested that the higher WD in the igapó is an adaptation to low
Table 2 Cross-correlations between diameter at breast height (dbh), and wood growth parameters (tree age, MRI, WD) of $V$. guianensis and T. barbata from the igapó and várzea (bold numbers)

The first number indicates the correlation coefficient $r$, the second number in brackets indicates the confidence-level $P$

\begin{tabular}{lllll}
\hline Tabebuia barbata & dbh & MRI & Tree age & WD \\
\hline Dbh & - & $0.14(0.56)$ & $0.57(<0.01)$ & $-0.15(0.52)$ \\
MRI & $\mathbf{0 . 0 5}(\mathbf{0 . 8 2})$ & - & $-0.65(<0.01)$ & $-0.60(<0.01)$ \\
Tree age & $\mathbf{0 . 4 3}(\mathbf{0 . 0 6})$ & $-\mathbf{0 . 8 5}(<\mathbf{0 . 0 0 1})$ & - & $0.37(0.11)$ \\
WD & $-\mathbf{0 . 2 6}(\mathbf{0 . 2 7})$ & $\mathbf{- 0 . 2 0}(\mathbf{0 . 4 1})$ & $-\mathbf{0 . 0 1}(\mathbf{0 . 9 9})$ & - \\
Vatairea guianensis & dbh & MRI & Tree age & WD \\
dbh & - & $-0.04(0.86)$ & $0.77(<0.001)$ & $0.26(0.27)$ \\
MRI & $-\mathbf{0 . 0 8}(\mathbf{0 . 7 3})$ & - & $-0.65(<0.01)$ & $-0.15(0.51)$ \\
Tree age & $\mathbf{0 . 3 5}(\mathbf{0 . 1 3})$ & $-\mathbf{0 . 7 9}(<\mathbf{0 . 0 0 1})$ & - & $0.29(0.20)$ \\
WD & $-\mathbf{0 . 1 2}(\mathbf{0 . 6 1})$ & $-\mathbf{0 . 0 2}(\mathbf{0 . 9 3})$ & $-\mathbf{0 . 0 8}(\mathbf{0 . 7 5})$ & - \\
\hline
\end{tabular}




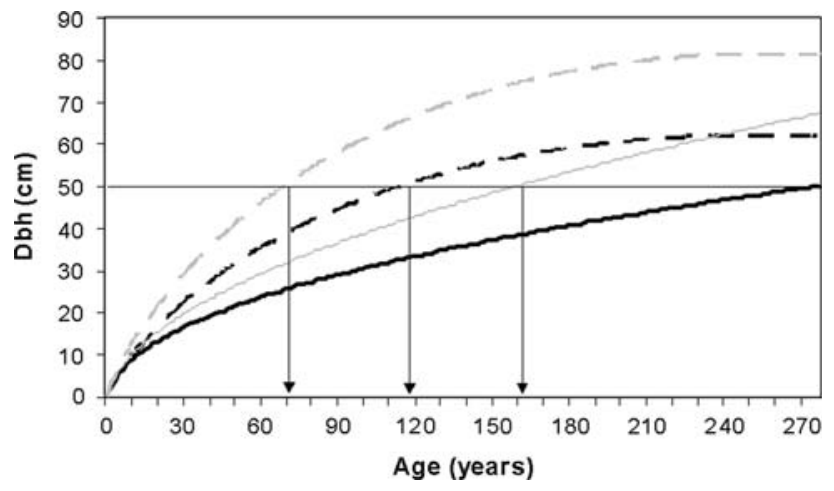

Fig. 5 Cumulative diameter growth curves T. barbata (black) and $V$. guianensis (gray) in the igapó (continuous line) and várzea (dotted line). The diameter cutting limit (MLD) of $50 \mathrm{~cm}$ is indicated

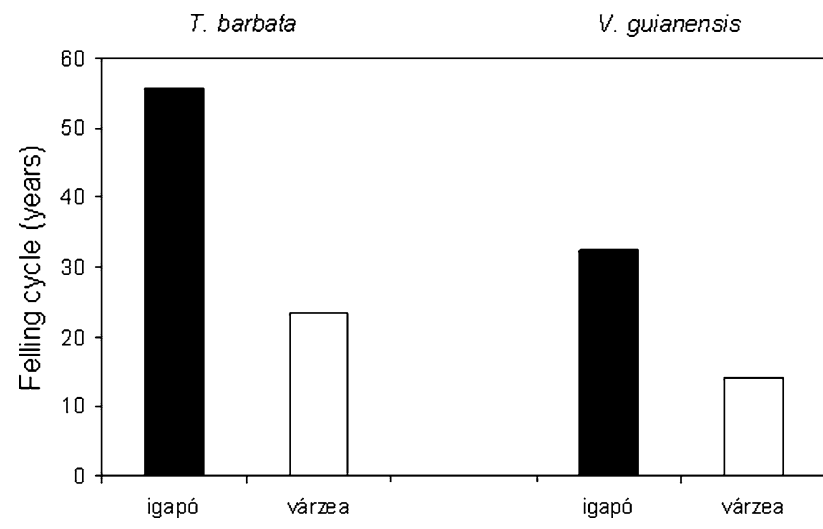

Fig. 6 Estimated felling cycles for $T$. barbata and $V$. guianensis in the igapó and várzea

nutrient conditions in their study. The WD of $T$. barbata was significantly higher in the nutrient-poor igapó $\left(\mathrm{WD}=0.65 \pm 0.02 \mathrm{~g} \mathrm{~cm}^{-3}\right.$ ) than in the nutrient-rich várzea (WD $=0.78 \pm 0.07 \mathrm{~g} \mathrm{~cm}^{-3}$ ) (see also Worbes et al. 1995). However, what Parolin and Ferreira (1998) did not consider was that the trees of $T$. barbata from the igapó grew in an old-growth forest, while those from the várzea originated from a young successional stage. Schöngart (2003) compared growth patterns of T. barbata between várzea forests of different successional stages and found a significantly lower WD in the young successional stage (WD $=0.65 \pm 0.07 \mathrm{~g} \mathrm{~cm}^{-3}$ ) than in an old-growth forest (WD $=0.84 \pm 0.10 \mathrm{~g} \mathrm{~cm}^{-3}$ ). Within the floodplain forests of the várzea, the MRI of T. barbata were about twice as high in young successional stages as in the climax stage (Worbes et al. 2001). However, in this study we compare tree growth of $T$. barbata in old-growth forests at both floodplain types subjected to an almost identical hydrological regime, and we do not find any significant differences in WD. The same holds for $V$. guianensis indicating no significant differences when comparing trees from igapó and várzea. Schöngart et al. (2005) showed that the legume tree species Macrolobium acaciifolium (Benth.) Benth. (Fabaceae) showed a significantly lower WD in the igapó than in the várzea comparing old-growth forests established at similar elevations. Thus it seems that no general conclusions can be made regarding whether WD of a tree species is higher in the igapó or in the várzea.

However, MRI differs significantly when comparing tree growth of $T$. barbata and $V$. guianensis in both floodplain types (Fig. 3). This finding is congruent with earlier studies comparing tree growth of $M$. acaciifolium in both systems (Schöngart et al. 2005). MRI of 45 tree species in the igapó $(\mathrm{MRI}=1.7 \mathrm{~mm}$ ) was less than the half the MRI of 158 species from the varzea $($ MRI $=3.5 \mathrm{~mm}$ ) (Worbes 1997). Also at the stand level a recent study confirmed much lower carbon sequestration rates in the aboveground coarse woody biomass of oldgrowth forests in the igapó when compared to old-growth forests at identical elevations in the várzea (Stadtler 2007). The lower increment rates of tree species and the lower productivity of stands in the igapó system indicate a different forest dynamic, which has to be considered in conservation plans for preservation and sustainable management.

For centuries, the Amazonian floodplains have been used and settled by a human population of high density that carried out agriculture, pasture, fishing and hunting, as well as the extraction of timber and non-timber products (Nebel and Meilby 2005; Schöngart et al. 2007) and floodplain forests are one of the most threatened forest ecosystems in the Amazon. One of the biggest obstacles in the sustained management of tropical forests is obtaining reliable data on the growth and yield of trees. Achieving sustainable yields requires species-specific management of timber resources, in which the different growth strategies of tree species and the varying site conditions are considered. Unfortunately, species-specific and site-specific management criteria based on wood growth data in the tropics are quite rare (Stahle et al. 1999; Schwartz et al. 2002; Sokpon and Biaou 2002; Nebel and Meilby 2005; Schöngart et al. 2008). For Amazonian forests, the restrictions in felling cycles and MLDs established in IN number 5 of IBAMA are estimations which are not derived from scientific data. The application of inadequate management criteria for a certain tree species under certain site conditions due to missing data on tree growth and natural regeneration can have negative effects on population structures. In this study, estimates for felling cycles vary almost fourfold between 14.0 years $(V$. guianensis at várzea site) and 55.6 years ( $T$. barbata at igapó site) (Fig. 6). Consequently, polycyclic systems operating with fixed felling cycles of 25-35 years would tend to overharvest the timber stocks in the igapó and to under-harvest timber stocks in the várzea. 
The igapó forests are especially vulnerable to inadequate timber management due to the slow dynamical processes reflected by the significantly lower MRI when compared to the várzea. The sustainable use of timber stocks in the nutrient-poor igapó is, under current management options, not sustainable due to low productivity. It is arguable, therefore, that a better use for floodplain forests of the igapó is to exclude them from timber-resource management for permanent protection as habitat for their highly diverse and partially endemic flora and fauna. In the várzea, however, a sustainable timber harvest is possible, but requires species-specific information on tree growth.

Acknowledgements This study was financed by the FEPIM Project 044/2003, GEOMA (Áreas Alagáveis), the INPA/Max-Planck Project as well as the Project 680021/2005-1 of the Brazilian Research Council $(\mathrm{CNPq})$ "Studies to sustain the community-based production in floodplain forests of the Mamirauá and Amanã Reserves". We are thankful for the comments of an anonymous reviewer.

Open Access This article is distributed under the terms of the Creative Commons Attribution Noncommercial License which permits any noncommercial use, distribution, and reproduction in any medium, provided the original author(s) and source are credited.

\section{References}

Ayres JM, Alves AR, Queiroz HL, Marmontel M, Moura E, Lima DM et al (1998) Mamirauá. Die Erhaltung der Artenvielfalt in einem amazonischen Überschwemmungswald. In: de Freitas MLD (ed) Amazonien: Himmel der Neuen Welt. Federal Ministry of Education and Research (in German: Bundesministerium für Building und Forschung, BMBF) Bonn, pp 262-274

Ayres JM, Fonseca GAB, Rylands AB, Queiroz HL, Pinto LP, Masterson D et al (2005) Os corredores ecológicos das florestas tropicais do Brasil. Sociedade Civil Mamirauá, Belém

Barros AC, Uhl C (1995) Logging along the Amazon River and estuary: patterns, problems, and potential. For Ecol Manage 77:87-105. doi:10.1016/0378-1127(95)03574-T

Brienen RJW, Zuidema PA (2006) Lifetime growth patterns and ages of Bolivian rain forest trees obtained by tree ring analysis. J Ecol 94:481-493. doi:10.1111/j.1365-2745.2005.01080.x

Dünisch O, Montóia VR, Bauch J (2003) Dendroecological investigations on Swietenia macrophylla King and Cedrela odorata L. (Meliaceae) in the central Amazon. Trees (Berl) 17:244-250

Ferreira LV (1997) Effects of the duration of floodplain on species richness and floristic composition in three hectares in Jaú National Park in floodplain forests in central Amazonia. Biodivers Conserv 6:1353-1363. doi:10.1023/A:1018385529531

Furch K (1997) Chemistry of várzea and igapó soils and nutrient inventory of their floodplain forests. In: Junk WJ (ed) The Central Amazon floodplains. Ecology of a pulsing system. Springer, Berlin, pp 47-67

Higuchi N, Hummel AC, Freitas JV, Malinowski JRE, Stokes R (1994) Exploração florestal nas várzeas do estado do Amazonas: Seleção de árvore, derrubada e transporte. In: Proceedings of the VII harvesting and transportation of timber products. IUFRO/ UFPR, Curitiba, pp 168-193

Junk WJ (1989) Flood tolerance and tree distribution in Central Amazonian floodplains. In: Nielsen LB, Nielsen IC, Baisley H (eds) Tropical forests: botanical dynamics, speciation and diversity. Academic, London, pp 47-64

Junk WJ, Bayley PB, Sparks RE (1989) The flood pulse concept in river-floodplain systems. Can Spec Publ Fish Aquat Sci 106:110-127

Kvist LP, Nebel G (2001) A review of Peruvian flood plain forests: ecosystems, inhabitants and resource use. For Ecol Manage 150:3-26. doi:10.1016/S0378-1127(00)00679-4

Lima JR, dos Santos J, Higuchi N (2005) Situação das indústrias madeireiras do estado do Amazonas em 2000. Acta Amazon 35:125-132

Loureiro AA, Freitas JA, Ramos CBL, Freitas CAA (2000) Essências madeireiras da Amazônia, vol 4. MCT/INPA-CPPF, Manaus

Nebel G, Meilby H (2005) Growth and population structure of timber species in Peruvian flood plains. For Ecol Manage 215:196-211. doi:10.1016/j.foreco.2005.05.017

Parolin P, Ferreira LV (1998) Are there differences in specific wood gravities between trees in várzea and igapo (Central Amazonia)? Ecotropica 4:25-32

Parolin P, De Simone O, Haase K, Waldhoff D, Rottenberger S, Kuhn $U$ et al (2004) Central Amazonian floodplain forests: tree adaptations in a pulsing system. Bot Rev 70:357-380. doi: 10.1663/0006-8101(2004)070[0357:CAFFTA]2.0.CO;2

Prance GT (1979) Notes on the vegetation of Amazonia III. Terminology of Amazonian forest types subjected to inundation. Brittonia 31:26-38. doi:10.2307/2806669

Rodrigues R (2007) Diversidade florística, estrutura da comunidade arbórea e suas relações com variáveis ambientais ao longo do Lago Amanã (RDSA), Amazônia Central. M.Sc. thesis, INPA, Manaus

Schöngart J (2003) Dendrochronologische Untersuchungen in Überschwemmungswäldern der várzea Zentralamazoniens. In: Böhnel H, Tiessen $\mathrm{H}$, Weidelt HJ (eds) Göttinger Beiträge zur Land- und Forstwirtschaft in den Tropen und Subtropen, vol 149. Erich Goltze Verlag, Göttingen

Schöngart J (2008) Growth-orientated logging (GOL): a new concept towards sustainable forest management in Central Amazonian várzea floodplains. For Ecol Manage 256:46-58. doi:10.1016/ j.foreco.2008.03.037

Schöngart J, Junk WJ (2007) Forecasting the flood-pulse in Central Amazonia by ENSO-indices. J Hydrol (Amst) 335:124-132. doi: 10.1016/j.jhydrol.2006.11.005

Schöngart J, Piedade MTF, Ludwigshausen S, Horna V, Worbes M (2002) Phenology and stem-growth periodicity of tree species in Amazonian floodplain forests. J Trop Ecol 18:581-597. doi: $10.1017 / \mathrm{S} 0266467402002389$

Schöngart J, Junk WJ, Piedade MTF, Ayres JM, Hüttermann A, Worbes M (2004) Teleconnection between tree growth in the Amazonian floodplains and the El Niño-Southern Oscillation effect. Glob Change Biol 10:683-692. doi:10.1111/j.15298817.2003.00754.x

Schöngart J, Piedade MTF, Wittmann F, Junk WJ, Worbes M (2005) Wood growth patterns of Macrolobium acaciifolium (Benth.) Benth. (Fabaceae) in Amazonian black-water and white water floodplain forests. Oecologia 145:454-461. doi:10.1007/s00442005-0147-8

Schöngart J, Wittmann F, Worbes M, Piedade MTF, Junk WJ (2008) Management criteria for Ficus insipida Willd. (Moraceae) in Amazonian white-water floodplain forests defined by tree-ring analysis. Ann For Sci 64:657-664. doi:10.1051/forest:2007044

Schwartz MW, Caro TM, Banda-Sakala T (2002) Assessing the sustainability of harvest of Pterocarpus angolensis in Rukwa Region, Tanzania. For Ecol Manage 170:259-269. doi:10.1016/ S0378-1127(01)00774-5

Sokpon N, Biaou SH (2002) The use of diameter distributions in sustained-use management of remnant forests in Benin: case of 
Bassila forest reserve in North Benin. For Ecol Manage 161:1325. doi:10.1016/S0378-1127(01)00488-1

Sombroek W (2001) Spatial and temporal patterns of Amazon rainfall. Ambio 30:388-396. doi:10.1639/0044-7447(2001)030 [0388:SATPOA]2.0.CO;2

Stadtler EWC (2007) Estimativas de biomassa lenhosa, estoque e seqüestro de carbono acima do solo ao longo do gradiente de inundação em uma floresta de igapó alagada por água preta na Amazônia Central. M.Sc. thesis, INPA, Manaus

Stahle DW, Mushove PT, Cleaveland MK, Roig F, Haynes GA (1999) Management implications of annual growth rings in Pterocarpus angolensis from Zimbabwe. For Ecol Manage 124:217-229. doi:10.1016/S0378-1127(99)00075-4

Wittmann F, Anhuf D, Junk WJ (2002) Tree species distribution and community structure of central Amazonian várzea forests by remote-sensing techniques. J Trop Ecol 18:805-820. doi: $10.1017 /$ S0266467402002523

Wittmann F, Schöngart J, Monteiro JC, Motzer T, Junk WJ, Piedade MTF et al (2006) Tree species composition and diversity gradients in white-water forests across in the Amazon Basin. J Biogeogr 33:1334-1347. doi:10.1111/j.1365-2699.2006. 01495.x
Wittmann F, Schöngart J, Brito JM, Oliveira-Wittmann A, Piedade MTF, Parolin P et al (2008) Manual of trees from Central Amazonian várzea floodplains: taxonomy, ecology, and use. Editora Valer, Manaus, Brazil (in press)

Worbes M (1988) Variety in structure of annual growth zones in Tabebuia barbata (E. Mey) Sandw., Bignoniaceae, a tropical tree species from Central Amazonian inundation forests. Dendrocronologia 6:71-89

Worbes M (1989) Growth rings, increment and age of trees in inundation forests, savannas and a mountain forest in the neotropics. IAWA Bull 10:109-122

Worbes M (1997) The forest ecosystem of the floodplains. In: Junk WJ (ed) The Central Amazon floodplains. Ecology of a pulsing system. Springer, Berlin, pp 223-266

Worbes M, Klosa D, Lewark S (1995) Rohdichtestruktur von Jahresringen tropischer Hölzer aus zentralamazonischen Überschwemmungswäldern. Holz Roh Werkst 53:63-67. doi: 10.1007/BF02716390

Worbes M, Piedade MTF, Schöngart J (2001) Holzwirtschaft im Mamirauá-Projekt zur nachhaltigen Entwicklung einer Region im Überschwemmungsbereich des Amazonas. Forstarchiv 72:188-200 